\section{Original} Article

\begin{tabular}{l} 
Access this article online \\
\hline Website: \\
www.ajobe.org \\
\hline DOI: \\
$10.4103 / 1817-7417.86026$ \\
\hline
\end{tabular}

Quick Response Code:

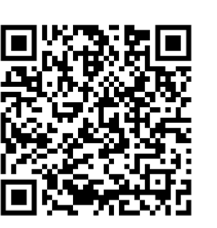

Address for Correspondence: Dr. Minka Woermann, Department of Philosophy, Stellenbosch University,

Private Bag X1, Matieland - 7602, South Africa.

E-mail: minka@sun.ac.za

\title{
In corporations we trust? A critique of contractarian- based corporate social responsibility models
}

\author{
Minka Woermann \\ Department of Philosophy, Stellenbosch University, Matieland, South Africa \\ ABSTRACT
}

This paper presents a philosophical critique of contractarian-based corporate social responsibility models. Specifically, attention is given to Freeman's (and Philips's) justification for voluntary agreements between corporations and their stakeholders. The critique is conducted at the hand of the claim that the social contract is a helpful tool for circumscribing the obligations of contracting parties, and that these derived obligations form a trust relation between the contracting parties. By analysing the logic of these relations, an argument is developed for why the structural conditions necessary to inspire trust in contracts are not met in the case of certain corporate-stakeholder relations.

Key words: Complexity, Corporate social responsibility, Relative power, Social contract theory, Stakeholders, Trust, Voluntary agreements

\section{INTRODUCTION}

The issue of corporate social responsibility (CSR) is one of the most longstanding and widely-debated topics in business ethics. Not only has the plethora of corporate scandals that continue to hit the corporate landscape kept the debate alive in recent years, but, so too, has the ever-increasing focus on sustainability and good governance. Indeed, one can argue that the responsibilities of large corporations ${ }^{1}$ have never been a more pertinent topic than today.

CSR is a theory that claims that corporations have obligations that exceed those required by law. Apart from financial success, such obligations typically include environmental and social responsibilities. An overview of the CSR literature suggests that there are two main approaches to conceptualising CSR. On the one hand, there is the social scientific approach; and, on the other hand, there is the normative approach. Those following the social scientific approach ${ }^{2}$ mostly fail to give a sufficient theoretical justification for the basis for corporations' indirect obligations. Attempts at providing a justification frequently amount to dogmatic claims, i.e., organisations have additional obligations due to the power that they exert in society; or empirical claims, i.e., it is in the interest of business to undertake such obligations, or society expects corporations to meet these additional obligations. Note that both these empirical claims provide reasons for why corporations should meet these additional obligations, but do not provide reasons for why such obligations exist in the first place.

The concern for providing a theoretical justification for organisational obligations that go beyond the law has mostly been undertaken by the second group of business ethicists, namely, philosophers. Several different kinds of support have been advanced in this regard, including utilitarian theories (Elfstrom); Kantian theories (Bowie); theories that combine moral rights, justice, and other kinds of moral principles (De George, Velasquez, Boatright); and, social contract theories (Donaldson, Freeman). It is beyond the scope of this paper to evaluate all these different justifications for CSR. As such, only a contractarian justification for CSR (particularly Freeman and Philips's justification, which is based on stakeholder theory) will be critiqued.

It will be shown that, when understood in terms of contracts or voluntary agreements, CSR theories run the risk of excluding certain stakeholders. These exclusions are neither 
explicit nor intentional but are the result of the logic of contracts or voluntary agreements. Such exclusions are revealed once one analyses the structural requirements of contracts, as well as the conditions that must be satisfied in order to instil trust in contractual models. This paper is, therefore, not aimed at presenting a model for understanding CSR, but rather seeks to expose potential weaknesses in a contractarian notion of CSR.

The paper begins with a general overview of a contractarian justification for business, as presented by Donaldson. This is followed by a more substantive discussion of Freeman's stakeholder-orientated view of CSR, which uses social contract theory in order to determine the nature of the obligations that managers have towards organisational stakeholders. In order to ascertain whether such a contractarian approach safeguards the interests of all stakeholders, a discussion of Annette Baier's work on the structural conditions needed to satisfy trust in, and, hence, safeguard the integrity of, contractual agreements is presented and applied to stakeholder-manager relations. The analysis concludes with a critical appraisal of CSR theories that attempt to derive organisational obligations from social contract theory. Here, particular attention is given to Freeman and Philips's theory.

\section{A contractarian justification for corporate social responsibility}

Thomas Donaldson is one of the earliest pioneers of contemporary business ethics. In his influential book, entitled Corporations and Morality (1982), he investigates the basis for a social contract for business ${ }^{3}$. He is of the belief that "[s] uch a contract would have concrete significance, for it would help to interpret the nature of the corporation's indirect obligations, which are notoriously slippery' (Donaldson, 1993: 167), as well as provide a justification for why organisations ought to exist (169). Donaldson turns to the political social contract to find support for this justification. He argues as follows: 'If the political contract serves as a justification for the existence of the state, then the business contract by parity of reason should serve as the justification for the existence of the corporation' (168).

In constructing a contract for business, Donaldson (173) uses the basic form for understanding a social contract, namely, "We (the members of society) agree to do $\mathrm{X}$, and you (the productive organizations) agree to do Y."' Donaldson then proceeds to substantiate $\mathrm{X}$ and $\mathrm{Y}$. The privileges that society grants corporations in return for meeting certain obligations are fairly easy to specify: society grants corporations legal status to act as a single agent, and the authority to own and use resources (173). Providing a justification for why societies should allow organisations to exist, and determining the obligations of these organisations are more challenging tasks. In order to specify society's terms for the social contract, Donaldson (174) suggests that we should imagine society without productive organisations. As such, we will need to a) characterise the conditions in a state of individual production (i.e., without productive organisations); b) indicate how certain problems are remedied by introducing productive organisations; and, c) use the list generated in the previous steps 'as a basis for specifying a social contract between society and its productive organizations' (174).

Using this methodology ${ }^{4}$, Donaldson is able to stipulate the terms of the contract that exists between members of society and productive organisations. The terms of this contract are as follows:

Corporations considered as productive organizations exist to enhance the welfare of society through the satisfaction of consumer and worker interests, in a way which relies on exploiting corporations' special advantages and minimizing disadvantages $(183-184)$.

This then constitutes the moral foundation of corporations, understood as productive organisations. Furthermore, the social contract serves as a tool for measuring the performance of corporations, and ensures that they meet their obligations towards society. If these obligations are not met, society is justified in condemning these corporations (184).

The question that might arise in the context of this analysis is, what leads society to accept this social contract and the principles upon which it is based? In an article that addresses frequently asked questions on the contractarian theory of morals, Jan Narveson (2003: 106) argues that the right set of principles to guide a social contract 'is the set that everyone, looking at those proposed principles from his or her point of view ex ante, can see that he or she will do better if everyone, including himself or herself, complies with those principles than if there are none or some other set.' These principles take the form of moral precepts which protect us from the depredation of others, and which allow for mutually beneficial cooperation (Narveson, 1988: 148). This point holds generally, although there very well might be individual instances when it would be in the favour of one of the parties or groups to break the social contract. For this reason, 'securing compliance is ... of critical importance to morals as social institutions.' (Narveson, 2003: 104).

The role and responsibilities formulated in the social contract between members of society and productive organisations are guided by rational moral precepts and directives, which override individual interest, and are, therefore, in a sense, authoritative (103). One is tempted to argue that this implicit social contract is no contract at all, since it isn't made but rather represents 'an identifiable disposition which anyone can adopt or not, independently of everyone else' (110). However, Narveson (110) argues 
that what makes the social contract contractual is 'that the disposition in question makes one's behavior a function of what other [groups] do.' The point is that, despite corporations being artificial groups, the precepts and directives established in this social contract apply to all business activities - whether they personally chose for it or not (102). Similarly, all societal groups must also reciprocate in terms of granting corporations certain privileges and rights.

In summary, the following characteristics can be identified for all forms of social contracts (Cudd, 2007): there is a clear characterisation of both the initial situation (as the starting point for a fair, impartial contract) and the groups participating in the contract; the contracting parties are rationally motivated to enter into a contract and thereby come to an agreement (the motivation can be either due to moral considerations or self-interested reasons); potential gains can be had from social interaction and cooperation; no one can be coerced into an agreement by another party; parties must agree to the terms/outcomes of the contract, i.e., the outcome must be fairly established; and, some form of recourse must exist if the contract is breached and the outcome not achieved.

\section{Freeman's model: Managing organisational} obligations towards stakeholders

The general terms of the social contract (as proposed in the above-mentioned earlier study by Donaldson) are relevant for this analysis. However, Donaldson and Dunfee's later work, as well as Freeman's model, extend the definition of societal members that are to be included in the social contract by incorporating other stakeholder groups besides consumers and workers (i.e., groups that have direct relevance to the firm's core economic activities). Indeed, the notion of stakeholder theory originates in the work of Freeman (1984), who is of the view that a productive organisation ought to be managed in a manner that balances the interests of all who bear a substantial relationship with the organisation (Marcoux, 2008). As such, Freeman (1994) collapses the distinction between the shareholder and stakeholder models of corporate social responsibility and, instead, argues in favour of a contractual model that focuses on joint value creation.

Freeman and Philips (2002: 334) maintain that in the first instance, it is management that is responsible for influencing, managing or balancing 'the set of relationships that can affect the achievement of an organization's purpose.' In order to successfully fulfil the managerial task, the basic negative rights [as referenced in Rawls' (1999) first principle ${ }^{5}$ ] of all contractors must be respected (this includes the property rights of shareholder and stakeholder groups); positive obligations should only be created through various voluntary actions; and, management and the affected contractors must take responsibility for the fulfilment of these voluntary agreements. The motivation for the voluntary management of stakeholder interests is that self-enforced responsible action limits the role of the state, and, therefore, guarantees maximal freedom for all contractors (including shareholders) (Freeman and Philips, 2002: 337-339). As such, the corporation can be described 'as a nexus of contracts or the centerpiece of an ongoing multilateral agreement, based on voluntary consent' (338).

Indeed, Freeman and Philips (341) claim that the hallmark of libertarian thesis (which they support) 'is one of consent and agreement. Free people have the right to make agreements with others, even if some of these arrangements limit their own freedom.' They continue in stating that business is founded upon the 'idea of making agreements with each other', and it is upon this basis that 'a set of positive obligations among those parties that are affected' by the agreement is created (341). From this basic premise, Freeman and Philips $(341 ; 342 ; 343)$ deduce a number of principles that capture the essence of this theory. For the purpose of this article, the three main principles ${ }^{6}$ will be discussed, namely:

- The Principle of Stakeholder Cooperation [,which] states that value is created because stakeholders can jointly satisfy their needs and desires by making voluntary agreements with each other.

- The Principle of Stakeholder Responsibility [,which] claims that parties to an agreement must accept responsibility for the consequences of their actions. When third parties are harmed, they must be compensated, or a new agreement must be negotiated with all of the parties who are affected.

- The Principle of Complexity [, which] claims that human beings are complex psychological creatures capable of acting from many different values and points of view.

With regard to The Principle of Stakeholder Cooperation, two characteristics are important: firstly, stakeholders must be free to engage in agreements; and secondly, an element of fairness must be present. In unfair cases, parties to the agreement must be free to seek alternatives, including state intervention (341). Note that if one adds The Principle of Stakeholder Responsibility to this first principle, fairness becomes a secondary matter, as people will generally concede to a strong notion of responsibility as a means of limiting regulation and, therefore, of preserving liberty. Another characteristic of this principle is that the notion of responsibility must apply reciprocally to all stakeholders: responsible action is not only the task of corporations (342). The last characteristic mentioned here, is The Principle of Complexity, which challenges the rigid notion that human beings are either completely self-interested or completely altruistic (343). Freeman and Philips (343) argue that humans should rather be viewed as complex creatures - 
capable of acting both altruistically and in a self-interested manner. They further state that ' [c]apitalism works because of this complexity, rather than in spite of it'. As such, capitalism can be viewed as 'the voluntary association of free, responsible, cooperating, consenting, and complex adults' (343). Given this definition, the task of management becomes 'to determine an answer to fundamental value questions that may bind together a business entity.' This is a necessary task since no 'right' answers exist in a complex system (343).

\section{The structure of contractual trust relations}

Donaldson's use of social contract theory for providing a moral justification for business (and for formulating an organisation's indirect obligations) does not use contract language to refer to the existence of actual contracts between corporations and their stakeholders. Rather, Donaldson accords the social contract hypothetical or ideal status. As such, the claim is that corporations and their stakeholders have certain expectations from one another, and have the power to do harm to one another if these expectations are not met. The relationship between corporations and their stakeholders can, therefore, be thought of as a social contract in that it is a helpful tool for spelling out the obligations of each party, without claiming that any explicit contract (apart from legally-mandated contracts) exists between the corporation and its stakeholders. From the above analysis, it is less clear whether Freeman (and Philips) also uses contracts in the same way as does Donaldson (that is, as a thought experiment from which organisational obligations can be derived). It seems that Freeman (and Philips) is implying that there are actual (non-legal) contractual agreements in place between organisations and their stakeholders.

Despite these (potential) differences between Donaldson and Freeman (and Philips), a convincing argument can be made that when the corporation translates the sentiments of the social contract into CSR policies or voluntary commitments to good governance or joint value creation, the hypothetical contract attains instrumental value and can be used as a tool for measuring organisational performance (as suggested by Donaldson). Furthermore, when stakeholder interests are articulated, a trust relation emerges between organisations and their stakeholders.

Indeed, in the introduction of the King III Report on Governance for South Africa, it is stated that '[s]urveys have shown that while the first priority of stakeholders of a company is the quality of the company's products or services, the second priority is the trust and confidence that the stakeholders have in the company' (IoD, 2010: 10). Therefore, good governance demands not only that the board remains accountable to the company itself, but also that the board takes notes of 'the legitimate interests and expectations of its stakeholders' (10). The issue of trust is also one of the primary motivations for instantiating the United Nation's (UN) Global Compact as a model for global CSR. Indeed, Bremer (2008: 228) reports that a central argument presented in support of the Global Compact, is that it can restore trust in private sector-led development, through fostering positive public perceptions of private sector performance. In this regard, Bremer (228) cites the following excerpt from the former UN Secretary General's (Kofi Annan) announcement on the founding of the Global Compact:

Globalization is a fact of life. But I believe we have underestimated its fragility. The problem is this. The spread of markets outpaces the ability of societies and their political systems to adjust to them, let alone to guide the course they take ... Our challenge today is to devise a ... compact on the global scale, to underpin the new economy.

Apart from these empirical examples, the following analysis of trust also shows why it is the case that a trust relation emerges as soon as the interests of legitimate stakeholders are mentioned and/or articulated. However, it will also be shown why it is necessary for stakeholders to critically appraise these trust relations with corporations.

In her celebrated article entitled 'Trust and Antitrust', Annette Baier defines trust as 'the trustor's expectation of being the recipient of the trusted party's good will' (paraphrase of Baier in Koehn, 2001: 184). From the above examples, we see that contractarian justifications for CSR claim that corporations and their stakeholders have certain expectations from one another. The assumption that such expectations will be met, therefore, hinges on a measure of trust between the contracting parties. If these expectations are not met, the parties have the power to damage each other. Implicit to a definition of trust is, therefore, a certain level of vulnerability on behalf of the trustor with regard to the extent of the trusted's good will. However, as Baier (1986: 235 ; 236) points out, such vulnerability is inevitable since - following two simple Socratic truths - we need the help of others in creating, and caring for, the things that we value, and, therefore, have no choice but to place ourselves in a position where others can harm us.

The structure of trust, on the above account, implies A trusting $B$ with a valued object $C$. According to this structure, trust implies entrustment (of an object $C$ in the care of $\mathrm{B}$ ), discretionary responsibility (B knowing what is entrusted $(\mathrm{C})$ by $\mathrm{A})$, and in some cases a form of relative power (where A is dependent in some sense upon B's goodwill) (236-244).

In terms of entrustment, Koehn (2001: 191) warns that identifying the trustor, trusted and object of trust, and determining when a trusting relationship exists, is often difficult, since such identifications are usually either theory- 
dependent or are frequently involuntarily created by our actions (and often have complex effects on unknown third parties) (see: Koehn, 2001: 191-195). Only in explicitly spelled out contractual relationships (Baier, 1986: 250) (such as the promissory relationship which might exist between principals and agents) could these categories be readily determined, and 'the legal system and other institutional apparatus can be trusted to interpret and enforce these contracts in a way that will not harm us' (Koehn, 2001: 187). One can, therefore, deduce that the more implicit and complex the relationship between the trustor, the trusted, and the object of trust, the higher the discretionary responsibility of the trusted, where discretionary responsibility is defined as knowing what it is that we have been entrusted with, as well as the levels and limits of our responsibility (Baier, 1986: 236-238).

Furthermore, 'the more extensive the discretionary power of the trusted, the less clear-cut will be the answer of when trust is disappointed' (238). This introduces another level of vulnerability as 'not yet noticed harm' or 'disguised ill will' (239). Koehn (2001: 188) elaborates on this point stating that individuals and corporations pursue their private ambitions at public expense by hiding behind claims that they are acting in the public trust' and that as such, 'uncritical reliance on [the subjectively determined goodwill of] another is at best morally neutral and frequently quite pernicious' (189).

This level of vulnerability is heightened in situations where there is a big difference in the two parties' relative power, and where the trustors are in need of 'positive help and substantial intervention in their lives' (187). Baier (1986: 241) argues that it is specifically these dependency relationships that cannot 'be grasped by looking at the morality of contract' which 'is designed for those equal in power [offering] an offensive pretense of equality as a substitute for its actuality' (249). Dependency relations, therefore, do not fit the contractual mould - which offers both explicitness and security to the 'cool distanced relations' between the equal, adult members of an 'all-males $\mathrm{club}^{\prime 7}(251 ; 248)$. This is because in these situations 'trust is maximal, rather than minimal, and because the vulnerable party has very little punitive power' (Koehn, 2001: 188 paraphrasing Baier (1985)).

Given the above analysis, Baier (1986: 249-250) concludes that since modern moral philosophy has concentrated mainly on the trust embedded in contractual relationships, it is not surprising that 'the main form of trust that any attention has been given to is trust in governments, and in parties to voluntary agreements to do what they have agreed to do.' However, she contends that the '[c]ontract is a device for traders, entrepreneurs, and capitalists, not for children, servants, indentured wives, and slaves' (247). The reason for this assertion is that in order to reasonably define when trust exists, the following conditions must be met: objects of trust must be easily identifiable; the trusted party's discretionary power must be limited; and, the relative power between the parties should be roughly equal. These conditions obviously only hold in very specific circumstances, i.e., where a level playing field exists.

Baier (252), therefore, concludes that 'a complete moral philosophy would tell us how and why we should act and feel towards others in relationships of shifting and varying power asymmetry and shifting and varying intimacy.' Such a moral philosophy cannot depend on punitive accountability and recourse as defined in a contractual sense, but will have to find a new way of responding to the marginalised, who nevertheless place their trust in the powerful.

\section{A critical appraisal of trust in contractually- defined business relations \\ Assessing shareholder and stakeholder relations as contractual trust agreements}

The question that now arises is, do corporate relations with shareholder and stakeholder groups fulfil the abovementioned structural conditions, necessary to inspire trust in contractually-defined corporate relations? Note that from this point onwards, the focus of this analysis is not on a contractarian justification for CSR, but rather on whether social contract theory is sufficient for deriving the (indirect) obligations of business, and measuring the performance of business with respect to these obligations. In this regard we see that, traditionally, corporate relations with shareholders are much better suited to a contractarian logic than corporate relations with stakeholders.

The normative ground for maintaining trust in the economic system is based on the structure of a contractual relationship. Economics rests on concrete matters, where I place my trust in the hands of a self-interested, distant others as long as I can hold them explicitly responsible for their actions, through means of formal complaint and redress if they break my trust (Jones, Parker and Ten Bos, 2005: 118). Practical problems that can arise include the fact that the initial conditions are not always well characterised, as shareholders usually do not purchase shares directly from companies, but rather from current shareholders. Shareholders also have no obligation to hold on to these shares, and can best be described as 'a far-flung, diverse, and ever-changing group.' (Shaw, 2011: 183). The idea of the promissory relationship between principal and agent [as conceptualised by Friedman (1962)] can, therefore, be contested, given the nature of our modern economic system.

However, having said this, one can still argue that shareholders buy shares on the grounds of certified financial statements, which serve as motivation to invest. That which is entrusted to the corporation and the grounds on which 
it is entrusted are, therefore, easily defined. Furthermore, shareholders will accept their losses if the corporation follows good governance principles, but will view them as a breach of contract if the company does not adhere to ethical prescriptions. The principle of accountability, whereby mechanisms exist that provide investors with the means to query and assess the actions of boards still remains essential in protecting the sanctity of the contract. This is because it limits the discretionary power of management, and heightens the power of the shareholder relative to the board and its committees. Given this account, it is maintained that the contractual relationships that exist between companies and shareholders represent a sound basis for trust.

Contractarian theory, as a way of deriving corporate social responsibilities, does not aid in safeguarding or protecting stakeholder interests, beyond denying the moral immunity of agents and principles. Used in the hypothetical sense, the social contract only loosely defines the stakes of stakeholders in terms of the risk that they pose to economic value, and the risk that they can potentially bear as a result of the value-creating process (Goodpaster, 1991: 54). It seems that, in many instances, corporate social responsibility practices still tacitly work with this vague notion of stakeholders. One of the reasons for this is that it is extremely complex for managers to apply, and work with, a broad notion of stakeholders, especially given 'the practical reality of limited resources, limited time and attention, and limited patience of managers for dealing with external constraints' (Mitchell, Agle and Wood, 1997: 857).

If, however, corporate actions have negative consequences for stakeholder groups, then it should be possible to attribute blame and deliver punishment to guilty corporations. Without accountability, loose organisational commitments to stakeholder interests cannot offer the functional excellences of certainty and security (Baier, 1986: 251) and end up trading 'on the positive connotation of the word [responsibility], but only loosely engages with anything that could be called responsibility in a stronger sense' (Jones et al., 2005: 123). In this context, stakeholders do not appear to have any true stakes in corporations that still deem their financial goals and objectives as central; and, that, at worst, view stakeholders as being 'a nuisance or opportunity that has to be managed' (123). Therefore, without substantial means to secure compliance, stakeholder interests are not sufficiently protected in the idea of the social contract - even when this contract is formalised in CSR policies.

According to Mitchell et al. (1997: 857), it is important to move towards a theory of stakeholder identification and salience, because in comprehensively defining stakeholder types, one can:

Equip managers with the ability to recognize and respond effectively to disparate, yet systematically comprehensible, set of entities who may or may not have legitimate claims, but who may be able to affect or are affected by the firm nonetheless, and thus affect the interests of those who do have legitimate claims.

In this regard, Freeman's work has been invaluable: in focusing attention on relations that create joint value, Freeman is able to spell out the rights, legitimate expectations, and responsibilities of various contractors ${ }^{8}$. These rights cannot be infringed upon by the corporation; however, stakeholders can freely enter into contracts or agreements with corporations in order to fulfil certain needs ${ }^{9}$. These agreements, which are managed by agents (managers or entrepreneurs), form positive obligations among the affected parties. Agents or managers must take responsibility for the effects of corporate actions, but so too must other stakeholders ${ }^{10}$.

These voluntary agreements, coupled with The Principle of Stakeholder Cooperation and The Principle of Stakeholder Responsibility, ensure that the conditions for a contract are sufficiently met: the parties to the agreement (and the conditions under which they enter an agreement) are clearly spelled out; the motivation for entering the agreement is joint value creation; cooperation and voluntary action form the basis of the agreement; and, parties must accept responsibility for their actions, including compensating third parties who are harmed by the contract (and, who in turn also have the right to enter into a renewed process of contract negotiation). Therefore, Freeman's re-inscription of stakeholder theory as a value-creating process between a corporation and its contractors seems to satisfy the conditions of trust: objects of entrustment are readily identified, thereby limiting the discretionary power of the agent; and, voluntary agreements, which are based on mutual consent, ensure relatively equal power relations between contracting parties.

\section{Problems with contractually-defined stakeholder-manager relations}

Freeman's re-conceptualisation of stakeholders as contractors goes a long way towards clarifying the types of relations different stakeholder groups have with the corporation. Obligations are not formulated in terms of abstract, general imperatives, but exist between discrete entities (Painter-Morland, 2006: 95). Such relationships require sensitivity to contingencies that may impact on the nature of the relationships, and it is in this sense that the managerial task is defined as not simply describing existing situations or predicting cause-effect relationships, but also recommending attitudes (Donaldson and Preston, 1995: 75-76). In other words, the managerial task is not merely descriptive or instrumental, but also normative. Indeed, in another context, Freeman (2008: 164) (following G. E. Moore) presents certain ethical questions that impact upon any business decision, namely: Who benefits or is harmed by value creation? Whose rights are enabled or 
disabled? And, how does one's decision affect the type of person one is/becomes? However, despite this sensitivity and awareness, it is suggested that more work needs to be done in this direction.

Taking the relational and contingent nature of stakeholder relations seriously, implies that one can no longer maintain that the voluntary agreement which exists between corporations and employees, for example, is the same in nature as the voluntary agreement which exists between corporations and communities. This is because there is a substantial difference in the relative strength, complexity and effects of these relations. Although Freeman and Philips (2002: 341) recognise that the latter agreement is more subtle, they nonetheless maintain that 'communities are also part of the agreement structure of business, since they provide air, water, schools, roads, protection from harm, and other so-called "public goods".' Communities are also considered as stakeholders precisely because they 'can affect or [are] affected by the achievement of the organization's objectives' (Freeman, 1984: 46). Freeman's definition of stakeholders is one of the broadest in the stakeholder literature, as it leaves the notions of 'stake' and 'stakeholder' open to include virtually anybody or any entity (Mitchell et al., 1997: 856). Excluded from the definition are only those who do not have the power to affect the organisation, or who are not affected by the organisation (i.e., have no claim or relationship with the organisation) (856). Although this definition is broad enough to cover all organisational claimants and influencers, it nevertheless does not help us to distinguish between differences in the nature of actual and potential stakeholder-manager relations. Indeed, Mitchell et al. (864) propose that these relations should be systematically unpacked in terms of the attributes of 'power, legitimacy, and/or urgency.'

In explaining the attribute of power, Mitchell et al. (865) draw on the Weberian notion of power, as 'the probability that one actor within a social relationship would be in a position to carry out his own will despite resistance' (Weber, 1947). Another definition of power mentioned by Mitchell et al. (1997: 865) is Pfeffer's rephrasing of Dahl's notion of power, as 'a relationship among social actors in which one social actor, A, can get another social actor, B, to do something that B would not otherwise have done' (Pfeffer, 1981: 3). Lastly, Mitchell et al. (1997: 865) agree with Salancik and Pfeffer (1974: 3) that power, although difficult to define, is easy to recognise as 'the ability of those who possess power to bring about the outcomes that they desire.' Mitchell et al. (1997: 866) make the point that power and legitimacy are often implicitly connected, although they need not be: even stakeholders with legitimate claims on the organisation will not achieve salience for the organisation's management, unless they have the power to enforce their will upon the organisation, or create the perception that their claim is urgent (866). Urgency, here, is understood either in terms of time sensitivity (i.e., 'the degree to which managerial delay in attending to the claim or relationship is unacceptable to the stakeholder') or criticality (i.e., 'the degree to which stakeholder claims call for immediate attention') (867).

When viewed in terms of these three attributes, it clearly becomes inappropriate to view all manager-stakeholder relations as consensual, voluntary agreements. This is because such agreements only account for the legitimacy of stakeholder claims, and do not necessarily attend to the attributes of power and urgency. According to Mitchell et al. (882), managers can only serve the interests of legitimate stakeholders, if these two latter attributes are also taken into account. However, if certain stakeholder groups are unable to articulate their legitimate claims and/or hold very little power over the organisation, it is unclear on what basis such stakeholders should trust organisations, as (in such cases at least) it seems impossible for stakeholders to hold organisations responsible or accountable for their actions. The reasons for why certain stakeholders are a) unable to articulate their legitimate claims and/or b) hold little or no power over organisations, are as follows:

\section{Objects of trust are difficult for indirect stakeholders to identify, especially given the pervasive effects of large corporations on society}

Certain stakeholders cannot readily be defined as adult individuals, as societies are complex constructions and systems within societies have unanticipated effects and repercussions within society - most of which can only be defined retrospectively, and cannot be linked to single individuals. Another way of stating this point is to say that there is no direct cause-and-effect relationship between two rational and willing parties (in this case, the corporation and a distant or abstract stakeholder group). Under these conditions, it is difficult to say exactly when third parties are harmed, what compensation would entail, or who should be called to the negotiation table, in order to establish a new agreement. Given this situation, it would seem reasonable to deduce that the founding principles of any contract as stipulated by Rawls (1993) (and appropriated by Freeman), namely, autonomy, solidarity and freedom, do not hold in the real world, and that contractually-based CSR models do not cope well with situations where corporate managers are distanced from the effects of corporate actions.

\section{Certain stakeholder groups place their trust in the goodwill of managers and boards who are invested with high levels of discretionary power.}

If certain stakeholder groups find it difficult to identify objects of entrustment, the discretionary responsibility vested in management serves not only to protect, but also to define, the interests of these stakeholders. Here it is difficult to see what equality among contractors might imply, and it seems likely that management will show 
bias in the interests that they serve to protect (namely, the interests of those contractors who directly add to the value-creation process, which in the first instance, still amounts to shareholder interests). This point becomes particularly pertinent given Freeman's description of stakeholder theory as a partly normative task. Although it is impossible (and undesirable) to escape the normative dimension of management, one should nevertheless pay careful attention to the issue of managerial goodwill, which as Koehn (2001: 185) points out, cannot be measured by any objective standard stipulated within an explicit contract. Adding to the problem is the fact that the conditions of trust in situations like these are maximal rather than minimal, precisely because stakeholder groups often do not have any substantive choice or means of redress (188) (unless their particular concerns are taken up by more powerful stakeholder groups such as NGOs, which can act on their behalf). Here the task of management must necessarily move beyond managing consensual, voluntary agreements aimed at fulfilling negative and positive obligations (which have already been circumscribed) in order to account for stakeholders who are powerless but who are, nevertheless, critically affected by the organisation's actions.

Whilst Freeman and Philips draw attention to the idea of moral/ethical complexity, it does not seem that this admittance has any affect on the type of relations that emerge from value-creating exercises (which are still defined as voluntary agreements that are the product of cooperating free wills). Nor does it seem that the element of complexity extends beyond the individuals participating in a value-creating exercise, to the system of value creation itself. As such, Freeman and Philips can describe capitalism as functioning due to complexity, without attributing any real significance to what this complexity might entail, and what affect it might have on stakeholders who do not stand in a direct, transparent, free and consenting relationship with the corporation.

To ignore these issues is to ignore the fact that management's discretionary responsibility (i.e., knowing what is entrusted to them by these stakeholders) and their ability to account for the criticality or urgency of the interests of powerless stakeholders (whether articulated or not) may be incongruent with what they perceive their obligations to be. CSR theories that attempt to derive organisational obligations from social contract theory, therefore, do not adequately account for all organisational obligations, and, therefore, do not sufficiently inspire stakeholder trust in business dealings.

\section{CONCLUSION}

It would seem that the contract, even when defined in libertarian terms, that allows for maximum freedom and autonomy of interacting parties still falls short in guaranteeing the protection of the rights of all stakeholder groups, the reason for this being that contracts often only function effectively in situations where parties are relatively equal. When this is not the case, one sees that the functional requirements needed for instilling trust in the contract may break down ${ }^{11}$. Contracts, therefore, cannot properly account for the 'shifting and varying power asymmetry' (Baier, 1986: 252) that characterises the relations between big corporations and marginalised stakeholder groups. This, however, does not imply that contracts should be done away with. Indeed, as Freeman rightly states, the process of value creation requires contracts or agreements between the corporation and various parties. Rather, the point is that if one takes the complex interactions between large corporations and society, as well as the effects of large corporations on society, seriously, one needs to concede to the fact that the contract is an insufficient device for securing responsible and accountable actions within certain contexts. Indeed the very questions Freeman poses - Who benefits or is harmed by value creation? Whose rights are enabled or disabled? And, how does one's decision affect the type of person one is/becomes? - cannot be properly responded to within the framework of voluntary agreements.

Obviously there are significant differences between stakeholder groups, and the question regarding the extent to which corporations can and should be held accountable for more indirect or abstract stakeholder groups has no simple answer. However, the argument is that, given the shortcomings of the contractual model, one should explore different strategies and ways in which corporations can articulate, appraise and commit to the responsibilities and obligations that they have towards stakeholders whose interests cannot be protected in contracts. Although it is difficult (if not impossible) to fully articulate these morally significant non-fiduciary obligations - or even to define towards whom corporations are obligated - we can, nevertheless, make a start by broadening our understanding of accountability. Such an understanding would move beyond the type of accountability that we refer to when we speak of contracts or voluntary agreements. Accountability in this re-conceptualisation would include an awareness of the impact that corporate relations have on those who are not in a position to spell out the obligations and responsibilities that corporations have towards them. However, further research is needed in order to determine exactly what such an understanding of accountability would entail, as well as to determine the impact that this revised notion of accountability would have on our understanding of the nature and scope of our corporate social responsibility practices.

Given the pressing issues with which we are grappling today, the question is no longer whether corporations need to accept increasing obligations within society, 
but rather how corporations should conceptualise these obligations. To place complete faith in contractual agreements is, according to this analysis at least, to ignore very real and important responsibilities towards certain stakeholders.

\section{ACKNOWLEDGEMENTS}

I would like to thank the anonymous reviewers who evaluated my paper during an earlier submission. Their inputs have greatly strengthened the quality and substance of my arguments.

\section{ENDNOTES}

1. In this paper, the terms 'corporation' and 'organisation' are used interchangeably.

2. See the work of Prakash Sethi, Lee Preston, Jerry Cavanagh, Donna Wood, Keith Davis, Ed Epstein, Jim Post, Archie Carroll, Bill Frederick, and George Steiner.

3. Since the publication of Corporations and Morality, Donaldson has collaborated with Dunfee (who argues that existing social contracts provide a source for moral guidance), and, together, they have authored another book, entitled Ties that Bind: $A$ Social Contracts Approach to Business Ethics (1999). In this book, they further develop the basis for a social contract in business, by elaborating on Integrative Social Contract Theory (ISCT). A discussion of ISCT is, however, beyond the scope of this paper.

4. See Donaldson (1993) for a full analysis of how the terms of the social contract are derived from this methodology.

5. Rawls (1999: 266) defines this principle as follows: 'Each person is to have an equal right to the most extensive total system of equal liberties compatible with a similar system of liberty for all.'

6. The other two principles mentioned in Freeman and Philips' article (2002: 334) are the 'The Principle of Continuous Creation' and 'The Principle of Emergent Competition'. Freeman maintains that 'these two principles are subsidiary to the first three' (334), and are necessary in order to correct the Standard Story of capitalism. The first of these principles places emphasis on the notion that human creativity is the real driver of capitalism and value creation; whereas the second principle operates as a corrective measure, ensuring that the creation of different stakeholder networks regulates the management task.

7. This statement is meant to emphasise the type of trust structures that operate within a phallocentric ideology, where the symbolic conventions of a male-dominated society operate at the expense of the marginalised.

8. Framed within the libertarian argument, Freeman and Philips (2002: 338) argue that stakeholders' rights can be defined as follows: 'Consumers have the property right to their wealth. Suppliers have the property right to the supplies that they sell to the corporation. Employees have a property right to their labor. Communities have a property right to public goods.'

9. The needs fulfilled through joint value creation are as follows: consumers purchase products; suppliers sell their products; employees work for some corporate objective in return for money, knowledge or/and satisfaction; and, communities enlarge their tax base (Freeman and Philips, 2002: 341).

10. Freeman and Philips (2002: 342) list the following stakeholder obligations: 'Customers have a duty to use products as they were intended ... Employees have a responsibility to support their employers within reason. Suppliers have the duty to make the supply base work properly and be efficient. And shareholders have a duty to elect responsible director'.

11. Obviously there are cases where implicit contracts between unequal parties can be effectively enforced (such as contracts between children and adults). However, where an unlevel playing field exits, the chance for contractual abuse by the more powerful party does exist. This possibility is implied in all three definitions of power, cited by Mitchell et al. earlier in this paper.

\section{REFERENCES}

Baier, A. 1985. 'What do women want in moral theory', Nous, 19, 3-56.

Baier, A. 1986. 'Trust and antitrust', Ethics, 96, 231-260.

Bremer, J.A. 2008. 'How global is the Global Compact?', Business Ethics: A European Review, 17(3), 227-244.

Cudd, A. 'Contractarianism', The Stanford Encyclopedia of Philosophy, Fall 2008 Edition. Available online at: < http://plato.stanford.edu/entries/ contractarianism/>

Donaldson, T. 1982. Corporations and morality. Engelwood Cliffs, NJ: Prentice Hall.

Donaldson, T. 1993. 'Constructing a social contract for business', in T.I. White, (Ed.) Business ethics: a philosophical reader. New York: MacMillan Publishing Company, 167-187.

Donaldson, T. and Dunfee, T.W. 1999. Ties that bind: a social contract approach to business ethics. Cambridge, MA: Harvard Business School Press.

Donaldson, T., and Preston, L.E. 1995. 'The stakeholder theory of the corporation: concepts, evidence, and implications', Academy of Management Review, 20(1), 65-91.

Freeman, R.E. 1984. Strategic management: a stakeholder approach. Boston: Pitman.

Freeman, R.E. 1994. 'The politics of stakeholder theory: Some future directions', Business Ethics Quarterly, 4, 409-421.

Freeman. R.E and Philips, R.A. 2002. 'Stakeholder theory: A libertarian defense', Business Ethics Quarterly, 12, 331-349.

Freeman, R.E. 2008. 'Ending the so-called "Friedman-Freeman" debate' in Agle, B.R., Donaldson, T., Freeman, R.E., Jensen, M.C., Mitchell, R.K. and Wood, D.J. 'Dialogue towards superior stakeholder theory', Business Ethics Quarterly, 18, 159-190.

Friedman, M. 1962. Capitalism and freedom. Chicago: University of Chicago Press.

Goodpaster, K.E. 1991. 'Business ethics and stakeholder analysis', Business Ethics Quarterly, 1, 53-73.

Institute of Directors, 2010. 'The King Report on governance for South Africa (King III)', Institute of Directors, 1 March 2010.

Jones, C., Parker, M., and Ten Bos, R. 2005. For business ethics. Oxon: Routledge.

Koehn, D. 2001. 'Should we trust in trust?', American Business Law Journal, 34, 183-203.

Marcoux, A. (2008) 'Business Ethics', The Stanford Encyclopedia of Philosophy, Fall 2008 Edition. Available online at: < http://plato.stanford. edu/entries/ethics-business/>

Mitchell, R.K., Agle, B.R. and Wood, D.J. 1997. 'Towards a theory of stakeholder identification and salience: Defending the principle of who and what really counts', Academy of Management Review, 22(4), 853-886.

Narveson, J. 1988. The libertarian idea. Philadelphia: Temple University Press.

Narveson, J. 2003. 'The contractarian theory of morals', Aufklaerung und Kritik, Sonderheft 7/2003, 100-122.

Painter-Morland, M. 2006. 'Redefining accountability as relational responsiveness', Journal of Business Ethics, 66, 89-98.

Pfeffer, J. 1981. Power in organizations. Marshfield, MA: Pitman.

Rawls, J. 1993. Political liberalism. New York: Columbia University Press.

Rawls, J. 1999. A theory of justice, rev. ed. Cambridge, MA: Harvard 
University Press.

Salancik, G.R. and Pfeffer, J. 1974. 'The base and use of power in organizational decision-making: The case of universities', Administrative Science Quarterly, 19, 453-473.

Shaw, W.H. 2011. Business ethics $7^{\text {th }}$ ed. Belmont: Thomson Wadsworth. Weber, M. 1947. The theory of social and economic organization. New
York: Free Press.

How to cite this article: ???.

Source of Support: Nil, Conflict of Interest: None declared

\section{AUTHOR}

Minka Woermann is a lecturer in Philosophy and is also Head of the Unit for Business Ethics and Public Integrity at the Centre for Applied Ethics, Stellenbosch University. Her research interests include ethics, business ethics, post-structural philosophy, and critical complexity theory. In 2010, she completed her doctoral dissertation, entitled 'A Complex Ethics: Critical Complexity, Deconstruction, and Implications for Business Ethics', and is currently reworking the dissertation into a book.

\section{Author Help: Online submission of the manuscripts}

Articles can be submitted online from http://www.journalonweb.com. For online submission, the articles should be prepared in two files (first page file and article file). Images should be submitted separately.

1) First Page File:

Prepare the title page, covering letter, acknowledgement etc. using a word processor program. All information related to your identity should be included here. Use text/rtt/doc/pdf files. Do not zip the files.

2) Article File:

The main text of the article, beginning with the Abstract to References (including tables) should be in this file. Do not include any information (such as acknowledgement, your names in page headers etc.) in this file. Use text/rtt/doc/pdf files. Do not zip the files. Limit the file size to $1 \mathrm{MB}$. Do not incorporate images in the file. If file size is large, graphs can be submitted separately as images, without their being incorporated in the article file. This will reduce the size of the file.

3) Images:

Submit good quality color images. Each image should be less than $\mathbf{4 0 9 6} \mathbf{~ k b ~ ( 4 ~ M B ) ~ i n ~ s i z e . ~ T h e ~ s i z e ~ o f ~ t h e ~ i m a g e ~ c a n ~ b e ~ r e d u c e d ~ b y ~}$ decreasing the actual height and width of the images (keep up to about 6 inches and up to about $1800 \times 1200$ pixels). JPEG is the most suitable file format. The image quality should be good enough to judge the scientific value of the image. For the purpose of printing, always retain a good quality, high resolution image. This high resolution image should be sent to the editorial office at the time of sending a revised article.

4) Legends:

Legends for the figures/images should be included at the end of the article file. 
Reproduced with permission of the copyright owner. Further reproduction prohibited without permission. 